\title{
Partial purification of $\left(\mathrm{Ca}^{2+}+\mathrm{Mg}^{2+}\right)$-dependent ATPase from pig smooth muscle and reconstitution of an ATP-dependent $\mathrm{Ca}^{2+}$-transport system
}

\author{
Frank WUYTACK, Greet DE SCHUTTER and Rik CASTEELS \\ Laboratorium voor Fysiologie, Universiteit Leuven, B-3000 Leuven, Belgium
}

(Received 3 February 1981/Accepted 22 April 1981)

(CaMg)ATPase $\left[\left(\mathrm{Ca}^{2+}+\mathrm{Mg}^{2+}\right)\right.$-dependent ATPase] was partially purified from a microsomal fraction of the smooth muscle of the pig stomach (antrum). Membranes were solubilized with deoxycholate, followed by removal of the detergent by dialysis. The purified (CaMg)ATPase has a specific activity (at $37^{\circ} \mathrm{C}$ ) of $157 \pm 12.1$ (7) $\mathrm{nmol} \cdot \mathrm{min}^{-1} \cdot \mathrm{mg}^{-1}$ of protein, and it is stimulated by calmodulin to $255 \pm 20.9$ (7) $\mathrm{nmol} \cdot \mathrm{min}^{-1} \cdot \mathrm{mg}^{-1}$. This purification of the $(\mathrm{CaMg})$ ATPase results in an increase of the specific activity by approx. 18 -fold and in a recovery of the total enzyme activity of $55 \%$ compared with the microsomal fraction. The partially purified $(\mathrm{CaMg}) \mathrm{ATPase}$ still contains some $\mathrm{Mg}^{2+}$ - and $\left(\mathrm{Na}^{+}+\mathrm{K}^{+}\right)$-dependent ATPase activities, but their specific activities are increased relatively less than that of the $(\mathrm{CaMg}) \mathrm{ATPase}$. The ratios of the $(\mathrm{CaMg}) \mathrm{ATP}$ ase to $\mathrm{Mg}^{2+}$ - and $\left(\mathrm{Na}^{+}+\mathrm{K}^{+}\right)$-dependent ATPase activities increase from respectively 0.14 and 0.81 in the crude microsomal fraction to 1.39 and 9.07 in the purified preparation. During removal of the deoxycholate by dialysis, vesicles were reconstituted which were capable of ATP-dependent $\mathrm{Ca}^{2+}$ transport.

$\mathrm{Ca}^{2+}$ plays an important role in the regulation of smooth-muscle contraction (Nonomura \& Ebashi, 1980). The estimated amount of $\mathrm{Ca}^{2+}$ that has to be removed from the cytoplasmic compartment in order to achieve full relaxation, as well as the gradients against which this $\mathrm{Ca}^{2+}$ is transported, are similar in smooth muscle and in skeletal muscle (van Breemen, 1977). Therefore an active $\mathrm{Ca}^{2+}$-transport system must be present in smooth muscle. Because of its slower relaxation, however, it can be assumed that the rate of removal of $\mathrm{Ca}^{2+}$ from the cytoplasm will be lower in smooth muscle than in fast skeletal muscle. We have previously shown that smoothmuscle microsomes (microsomal fraction) can accumulate $\mathrm{Ca}^{2+}$ in an ATP-dependent way (Raeymaekers et al., 1977; Wuytack et al., 1978) and that the $(\mathrm{CaMg}) \mathrm{ATPase}$ activity present in this microsomal fraction might be related to the $\mathrm{Ca}^{2+}$-transport system (Wuytack \& Casteels, 1980). We now report a partial purification of this (CaMg)ATPase from a smooth-muscle microsomal fraction. This purification relies on the use of deoxycholate and is comparable with the method used by Meissner \& Fleischer (1974) on fragmented sarcoplasmic reticulum of skeletal muscle. This technique has also

Abbreviations used: (CaMg)ATPase, $\left(\mathrm{Ca}^{2+}+\mathrm{Mg}^{2+}\right)$ dependent ATPase, (NaK)ATPase, $\left(\mathrm{Na}^{+}+\mathrm{K}^{+}\right)$-dependent ATPase; MgATPase, $\mathbf{M g}^{2+}$-dependent ATPase. been applied to the partial purification and reconstitution of the $\mathrm{Ca}^{2+}$-transport system in erythrocytes (Gietzen et al., 1980). By removing carefully the deoxycholate from the solubilized ( $\mathrm{CaMg})$ ATPase of smooth muscle, vesicles were reconstituted which are capable of ATP-dependent $\mathrm{Ca}^{2+}$ transport.

\section{Methods}

\section{Preparation of the microsomal fraction}

Although pig antral smooth muscle is a less pure smooth-muscle tissue than the media-intima preparation of the pig coronary artery routinely used in our laboratory (Wuytack et al., 1978), we have selected this tissue for the purification of $(\mathrm{CaMg})$ ATPase because it can easily be obtained in large quantities. Antral parts of pig stomachs were obtained at the slaughterhouse and transported to the laboratory with the mucosal side resting on ice. In the laboratory the mucosa was removed by scissors, together with fat, blood vessels and mesenteric membranes. The remaining smooth muscle was cut into strips approx. $1 \mathrm{~cm}$ wide, which were quickly frozen in liquid nitrogen, and stored at $-80^{\circ} \mathrm{C}$. Freezing of the tissues allowed us to collect more material before starting the purification of the (CaMg)ATPase.

For homogenization, approx. $100 \mathrm{~g}$ of frozen 
tissue was thawed in $7 \mathrm{vol}$. of homogenization medium, containing $100 \mathrm{~mm}$-sucrose, $0.5 \mathrm{~mm}$-phenylmethanesulphonyl fluoride, $0.1 \mathrm{mM}$-7-amino-1chloro-3-L-p-tosylamidoheptan-2-one ('TLCK'), $0.5 \mathrm{~mm}$-benzamidine and $1 \mathrm{~mm}$-dithiothreitol. The thawed tissues were taken out of the medium and passed through a tissue press, equipped first with a sieve plate with $1 \mathrm{~mm}$ holes and then with a sieve plate with $0.5 \mathrm{~mm}$ holes.

The material squeezed through the press was returned to the homogenization medium and homogenized in a blender (Braun type MX32GR; Braun A.G., Frankfurt, West Germany) for 20 s at maximal speed. Then the homogenate was given two up-and-down strokes of the pestle in a glass/Teflon Potter homogenizer (type S, $60 \mathrm{ml}$; B. Braun, Melsungen, West Germany) at $1500 \mathrm{rev} . / \mathrm{min}$. This homogenate was centrifuged in a Sorvall GS3 rotor at $6500 \mathrm{rev} . / \mathrm{min}\left(7150 \mathrm{~g}_{\max }\right)$ for $15 \mathrm{~min}$. The pellets and floating material were removed and the supernatant was again centrifuged in a Sorvall GSA rotor at $13000 \mathrm{rev} . / \mathrm{min}$ for $20 \mathrm{~min}\left(27600 \mathrm{~g}_{\text {max }}\right)$. The supernatant was then centrifuged in a Beckman type 19 rotor at $19000 \mathrm{rev} . / \mathrm{min}\left(53700 \mathrm{~g}_{\max }\right)$ for $150 \mathrm{~min}$ and the pellet was resuspended in $40 \mathrm{ml}$ of $0.1 \mathrm{M}$ sucrose with a Teflon/glass Potter homogenizer. A sample of this suspension was taken for further analysis $\left(\mathbf{P}_{\text {crude }}\right)$.

\section{Extraction of the microsomal fraction with $\mathrm{KCl}$}

This crude microsomal fraction was mixed with an equal volume of $1.4 \mathrm{M}-\mathrm{KCl}$ in $10 \mathrm{mM}$-imidazole/ $\mathrm{HCl}, \mathrm{pH} 6.8$, and gently stirred at $4^{\circ} \mathrm{C}$ for $1 \mathrm{~h}$. The suspension was then centrifuged in a Kontron (Kontron, Zürich, Switzerland) TFT 50.38 rotor at $35000 \mathrm{rev} . / \mathrm{min}\left(150000 \mathrm{~g}_{\max }\right.$. $)$ for $35 \mathrm{~min}$, and the pellet resuspended with a Teflon/glass Potter homogenizer in $10 \mathrm{ml}$ of $0.25 \mathrm{M}$-sucrose. This $\mathrm{KCl}$-extracted fraction $\left(P_{K C l}\right)$ was kept overnight at $4^{\circ} \mathrm{C}$ for extraction with deoxycholate the next day.

\section{Solubilization of the microsomal fraction with deoxycholate}

After measurement of the protein concentration in the $\mathbf{P}_{\mathrm{KCl}}$ fraction, the microsomes were centrifuged for $30 \mathrm{~min}$ in a Beckman Ti 75 rotor at $50000 \mathrm{rev}$./ $\min \left(223800 g_{\max }\right)$ and the pellet was resuspended in a volume of extraction buffer [10 mM-Tris/ $\mathrm{HCl}$ (pH 7.9)/400 mM-sucrose $/ 450 \mathrm{~mm}-\mathrm{KCl} / 1 \mathrm{~mm}$ EDTA / $1.5 \mathrm{~mm}-\mathrm{MgCl}_{2} / 0.1 \mathrm{mM}-\mathrm{CaCl}_{2} / 1 \mathrm{~mm}$-dithiothreitol] to obtain a calculated protein concentration of $10 \mathrm{mg} / \mathrm{ml}$. The resuspended microsomes were distributed over a series of tubes and to each tube an equal volume of a deoxycholate solution in extraction buffer was added. The detergent/protein ratio obtained varied between $1: 50$ and $2: 1$ (w/w). The tubes were stirred slowly with a magnetic stirrer for $10 \mathrm{~min}$ at $4^{\circ} \mathrm{C}$, and the unsolubilized material was removed by centrifugation for $30 \mathrm{~min}$ in a Beckman $\mathrm{Ti} 75$ rotor at $50000 \mathrm{rev} . / \mathrm{min}$ $\left(223800 g_{\text {max. }}\right)$.

\section{Removal of the deoxycholate and membrane re-} constitution

A sample of the supernatant (usually $1.5 \mathrm{ml}$ ) was dialysed against a large volume of dialysis buffer \{10mm-Hepes [4-(2-hydroxyethyl)-1-piperazineethanesulphonic acid] (pH 7.0)/250 mM-sucrose/ $400 \mathrm{~mm}-\mathrm{KCl} / 1 \mathrm{~mm}$-EDTA / $1.5 \mathrm{mM}-\mathrm{MgCl}_{2} / 0.1 \mathrm{mM}$ $\mathrm{CaCl}_{2} / 1 \mathrm{mM}$-dithiothreitol $\}$, first for $4 \mathrm{~h}$ at $22^{\circ} \mathrm{C}$ and thereafter overnight at $4^{\circ} \mathrm{C}$. The dialysed fractions were diluted with $4 \mathrm{vol}$. of $0.25 \mathrm{M}$-sucrose and centrifuged for $30 \mathrm{~min}$ in the Beckman $\mathrm{Ti} 75$ rotor at $50000 \mathrm{rev} . / \mathrm{min}\left(223800 \mathrm{~g}_{\text {max }}\right)$. The pellets were resuspended in $0.25 \mathrm{M}$-sucrose with a glass/Teflon Potter homogenizer.

\section{Assays}

ATPases were measured by using a coupled enzyme assay in which the ATP hydrolysis is coupled to NADH oxidation (Wuytack \& Casteels, 1980). The reaction medium ( $1 \mathrm{ml})$ contained: $100 \mathrm{~mm}-\mathrm{KCl}, \quad 30 \mathrm{~mm}$-imidazole $/ \mathrm{HCl} \quad(\mathrm{pH} 6.8)$,

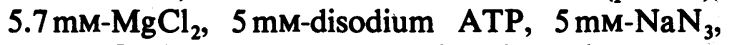
1 mM-EGTA, $\quad 1.5 \mathrm{~mm}$-phosphoenolpyruvate, $0.26 \mathrm{~mm}$-disodium NADH, pyruvate kinase (40units $/ \mathrm{ml}$ ), lactate dehydrogenase (36 units $/ \mathrm{ml}$ ) (both enzymes from rabbit muscle). After thermal equilibration, a small sample of ATPase was added to the cuvette to start the reaction. The decrease in $A_{340}$ was recorded. Subsequently, each time after an interval of $2 \mathrm{~min}, 0.1 \mathrm{~mm}$-ouabain, $0.87 \mathrm{~mm}-\mathrm{CaCl}_{2}$ and calmodulin $(10 \mu \mathrm{g} / \mathrm{ml})$ were added. The $(\mathrm{NaK})-$ ATPase activity was calculated from the difference in slope before and after addition of ouabain, that of MgATPase from the slope in the presence of ouabain and that of $(\mathrm{CaMg}) \mathrm{ATPase}$ from the difference in the slope before and after addition of $\mathrm{CaCl}_{2}$. The free $\mathrm{Ca}^{2+}$ concentration in this condition amounted to $10 \mu \mathrm{M}$. A molar absorption coefficient, $\varepsilon$, of $6200 \mathrm{M}^{-1} \cdot \mathrm{cm}^{-1}$ was used.

$\mathrm{Ca}^{2+}$ uptake was measured by using the Millipore filtration method at $\left[\mathrm{Ca}^{2+}\right]=10 \mu \mathrm{M}$, as described by Wuytack \& Casteels (1980). (CaMg)ATPase and $\mathrm{Ca}^{2+}$ uptake were determined at $37^{\circ} \mathrm{C}$.

\section{Electrophoresis}

Dodecyl sulphate/polyacrylamide-gel electrophoresis was done in a discontinuous buffer system as described by Laemmli (1970), with a stacking gel of $3 \%$ and a separating gel of $10 \%(w / v)$ acrylamide.

\section{Protein}

Protein was measured by the method of Lowry et al. (1951). To remove interference from buffers and 
other additives with this technique, proteins were precipitated with trichloroacetic acid, followed by resolubilization in $\mathrm{NaOH}$. Bovine serum albumin was used as a standard.

\section{Materials}

Deoxycholate (sodium salt), benzamidine hydrochloride, dithiothreitol and NADH were obtained from Sigma, 7-amino-1-chloro-3-L-p-tosylamidoheptan-2-one was from Serva, and phenylmethanesulphonyl fluoride, pyruvate kinase and lactate dehydrogenase were from Boehringer. Calmodulin was prepared from bovine brain as described by Sharma \& Wang (1979).

\section{Results}

Microsomal fractions from smooth muscle of the antral part of the pig stomach have an ATPdependent $\mathrm{Ca}^{2+}$ uptake which is stimulated by the presence of oxalate (Fig. 1), and also a (CaMg)ATPase activity (Table 1).

\section{Effect of $\mathrm{KCl}$ extraction on the microsomal fraction}

Some $60 \%$ of the proteins present in the microsomal fraction appear to be not, or only loosely, associated with the membranes and can therefore easily be removed by a single wash in $0.7 \mathrm{M}-\mathrm{KCl}$ (see the Methods section). The specific activities of $\mathrm{Ca}^{2+}$ transport and of (NaK)ATPase, MgATPase and $(\mathrm{CaMg}) \mathrm{ATPase}$ increase accordingly (Table 1).

Solubilization of the microsomal fraction by deoxycholate

$\mathrm{KCl}$-extracted microsomes $\left(\mathrm{P}_{\mathrm{KCl}}\right)$ were solubilized with deoxycholate at detergent/protein ratios between $1: 50$ and $2: 1(\mathrm{w} / \mathrm{w})$, as described for fragmented sarcoplasmic reticulum by Meissner \& Fleischer (1974). Fig. 2 gives values for the protein and for the total activity (in $\mathrm{nmol} \cdot \mathrm{min}^{-1}$ ) of the different ATPases solubilized from $10 \mathrm{mg}$ of protein of $\mathbf{P}_{\mathrm{KCl}}$ fraction as a function of the deoxycholate/protein ratio $(w / w)$. The values given in Fig. 2 apply to the fractions after removal of detergent by dialysis, as described in the Methods section. The values for protein and for total activities of ATPases can be compared with the corresponding values for protein and total activity before extraction, which are also given in the legend of Fig. 2.

The following conclusions can be drawn.

(1) By increasing the deoxycholate/protein ratio, increasing amounts of protein are solubilized. At a ratio of $2: 1$, about $30 \%$ of the protein is in solution.

(2) The (CaMg)ATPase, measured in the absence or presence of saturating amounts $(10 \mu \mathrm{g} / \mathrm{ml})$ of calmodulin, shows the highest total activity after solubilization at a detergent/protein ratio of 0.2 . At higher detergent/protein ratios the activity decreases again.
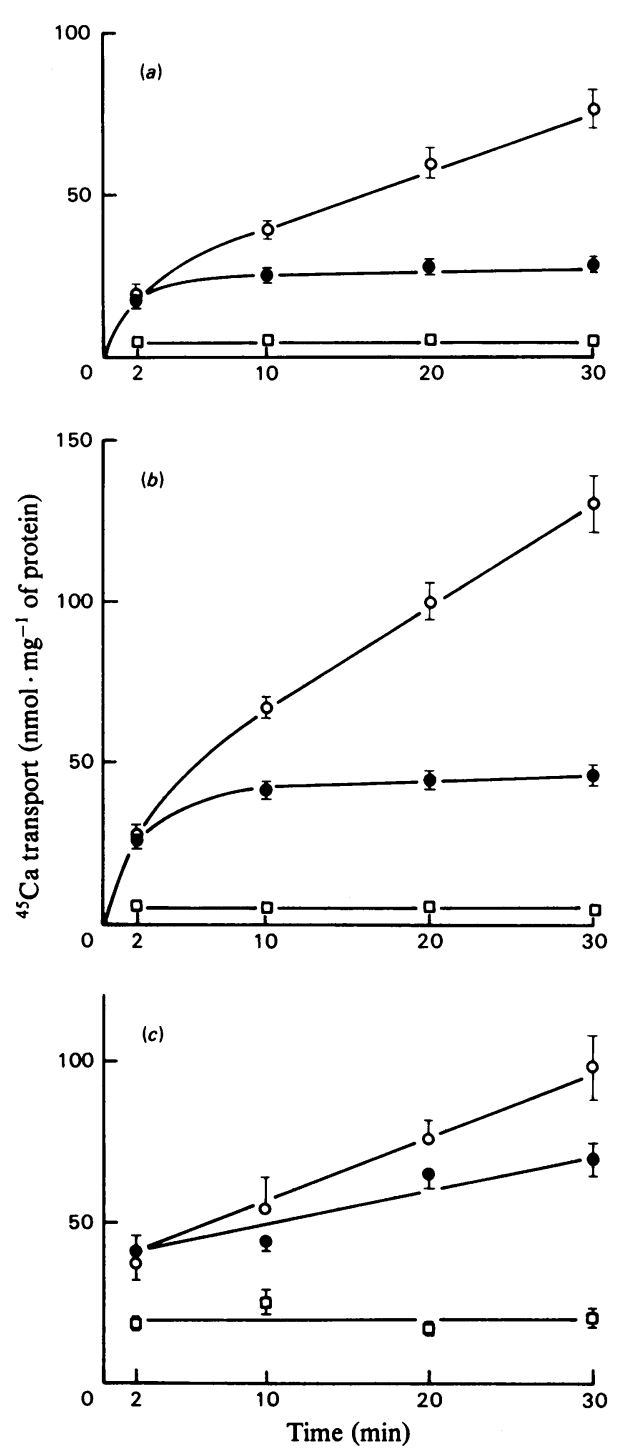

Fig. $1 .{ }^{45} \mathrm{Ca}$ transport measured in microsomal fractions from pig antrum smooth muscle

$\mathrm{Ca}^{2+}$ accumulation was measured at $37^{\circ} \mathrm{C}$ and $\left[\mathrm{Ca}^{2+}\right]=10 \mu \mathrm{M}$ by the Millipore filtration technique (see the Methods section): $\square$, in the absence of ATP; 0 , in the presence of $5 \mathrm{mM}$-ATP and without oxalate; $O$, in the presence of $5 \mathrm{~mm}$-ATP and 5 mM-oxalate. No calmodulin was added in these experiments. (a) represents accumulation in $\mathbf{P}_{\text {crude }}$ (crude microsonal fraction), (b) in $\mathrm{P}_{\mathrm{KCl}}$ ( $\mathrm{KCl}$ extracted microsomal fraction) and (c) in the $\mathbf{P}_{\mathrm{d} 0.2}$ (reconstituted vesicles obtained after dialysis of material solubilized from $\mathbf{P}_{\mathbf{K C l}}$ at a deoxycholate/ protein ratio of 0.2 ). The symbols are mean values, with vertical bars representing \pm S.E.M. The number of observations was eight for $\mathbf{P}_{\text {crude }}$ and $\mathbf{P}_{\mathrm{KCl}}$, and five for $\mathbf{P}_{\mathrm{d} 0.2}$. 
Table 1. Effect of $\mathrm{KCl}$ extraction of the microsomes on protein content and ATPase activities

Protein content $\left[\mathrm{mg}\right.$ of protein $\left.\cdot(100 \mathrm{~g} \text { wet wt. of tissue })^{-1}\right]$ and specific activities $\left(\mathrm{nmol} \cdot \mathrm{min}^{-1} \cdot \mathrm{mg}^{-1}\right.$ of protein) of the ATPases are given for crude microsomes $\left(\mathrm{P}_{\text {crude }}\right)$ and $\mathrm{KCl}$-extracted microsomes $\left(\mathrm{P}_{\mathrm{KCl}}\right)$. The last line gives also the mean increase in specific activity of $(\mathrm{CaMg}) \mathrm{ATPase}$ in the presence of calmodulin. All values are means \pm S.E.M. for the numbers of observations given in parentheses.

\begin{tabular}{lccc} 
& & & $\frac{P_{\mathrm{KCl}}}{\mathbf{P}_{\text {crude }}}$ \\
Protein $(\mathrm{mg} / 100 \mathrm{~g}$ of tissue) & $298 \pm 21.7(9)$ & $112 \pm 2.6(9)$ & $0.37 \pm 0.03(9)$ \\
MgATPase & $52 \pm 4.7(8)$ & $118 \pm 5.0(8)$ & $2.4 \pm 0.16(8)$ \\
(NaK)ATPase & $10 \pm 1.1(8)$ & $21 \pm 2.0(8)$ & $2.2 \pm 0.26(8)$ \\
(CaMg)ATPase & $11 \pm 1.6(8)$ & $32 \pm 3.5(8)$ & $3.2 \pm 0.34(8)$ \\
+ Calmodulin $(10 \mu \mathrm{g} / \mathrm{ml})$ & $19 \pm 2.4(8)$ & $58 \pm 5.0(8)$ & $3.4 \pm 0.37(8)$ \\
+ Calmodulin & & & \\
\hline - Calmodulin & $1.8 \pm 0.7(8)$ & $1.9 \pm 0.1(8)$ &
\end{tabular}

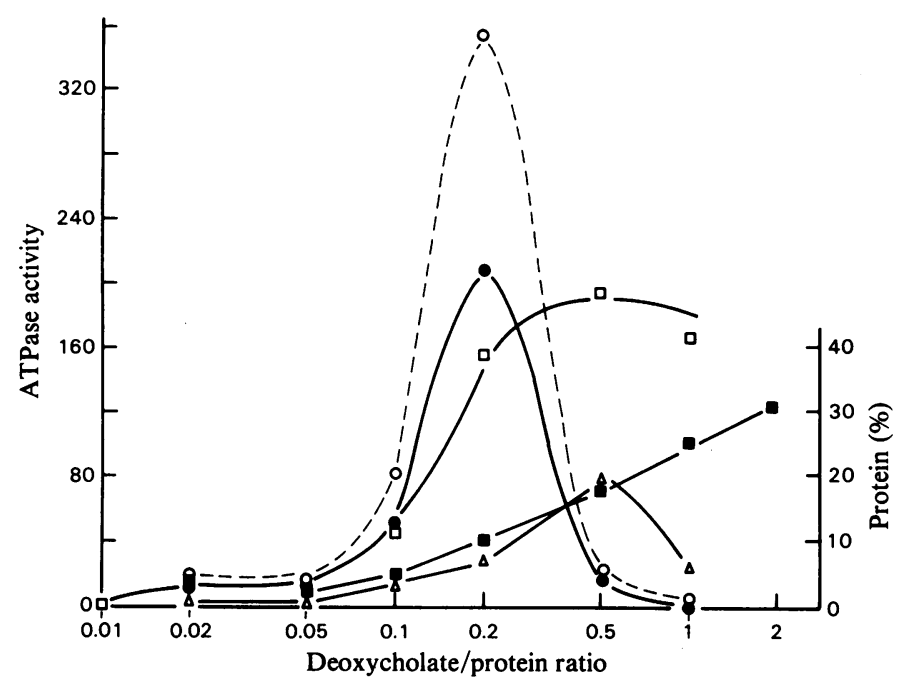

Fig. 2. Solubilization of protein and ATPases from the microsomes as a function of the deoxycholate/ protein ratio The total activity of ATPase $\left(\mathrm{nmol} \cdot \mathrm{min}^{-1}\right.$ ) and protein (\%) solubilized from $10 \mathrm{mg}$ of $\mathbf{P}_{\mathbf{K C l}}$ fraction as a function of the deoxycholate/protein ratio $(\mathrm{w} / \mathrm{w})$ is shown. The values are those obtained after dialysis (see the Methods section) and can be compared with the following total activities in $10 \mathrm{mg}$ of protein of the $\mathbf{P}_{\mathrm{KCl}}$ fraction $\left(\mathrm{nmol} \cdot \mathrm{min}^{-1}\right)$ : MgATPase, 1223; (NaK)ATPase, 227; (CaMg)ATPase, 417; (CaMg)ATPase in the presence of calmodulin $(10 \mu \mathrm{g} / \mathrm{ml})$, 707. - Protein; $\square, \mathrm{MgATPase} ; \triangle$, (NaK)ATPase; $\bullet$, (CaMg)ATPase without calmodulin; 0 , (CaMg)ATPase with calmodulin. The values are means of three observations.

(3) The (NaK)ATPase requires for maximal solubilization a higher detergent/protein ratio $(0.5)$ than the $(\mathrm{CaMg})$ ATPase. Like $(\mathrm{CaMg})$ ATPase, the activity of the ( $\mathrm{NaK}) \mathrm{ATPase}$ is decreased again by a further increase in detergent.

(4) Most of the MgATPase activity is already solubilized at a detergent/protein ratio of 0.2 . A further increase in this ratio does not diminish the total activity of MgATPase, as has been observed for the (NaK)ATPase and $(\mathrm{CaMg})$ ATPase.

Solubilization of the $\mathrm{KCl}$-extracted microsomes at a ratio of $0.2 \mathrm{mg}$ of deoxycholate to $1 \mathrm{mg}$ of protein therefore yields the highest activity of (CaMg)ATPase in the dialysed supernatant $\left(P_{d 0.2}\right)$. Table 2 gives the specific and total activities (per $100 \mathrm{~g}$ wet wt. of tissue) of the ATPase activities as well as the recovery during the purification procedure. These values of the $(\mathrm{CaMg}) \mathrm{ATPase}$ activity both in the presence and in the absence of calmodulin clearly show the selective purification. Whereas we recover in the final $\mathbf{P}_{\mathrm{d} 0.2}$ preparation only slightly more than $7 \%$ of both the total MgATPase and (NaK)ATPase activities, we obtain more than $50 \%$ of the total $(\mathrm{CaMg}) \mathrm{ATPase}$ activity. The recovery is greater for 
Table 2. Purification of the (CaMg)ATPase

Specific activity $\left(\mathrm{nmol} \cdot \mathrm{min}^{-1} \cdot \mathrm{mg}^{-1}\right.$ of protein), total activity $\left[\mu \mathrm{mol} \cdot \mathrm{min}^{-1} \cdot(100 \mathrm{~g} \text { of tissue })^{-1}\right]$ and recovery (\%) of MgATPase, (NaK)ATPase and ( $\mathrm{CaMg}$ )ATPase in the absence and presence of calmodulin during purification are shown. Values are means \pm 1 S.E.M. for the numbers of observations shown in parentheses.

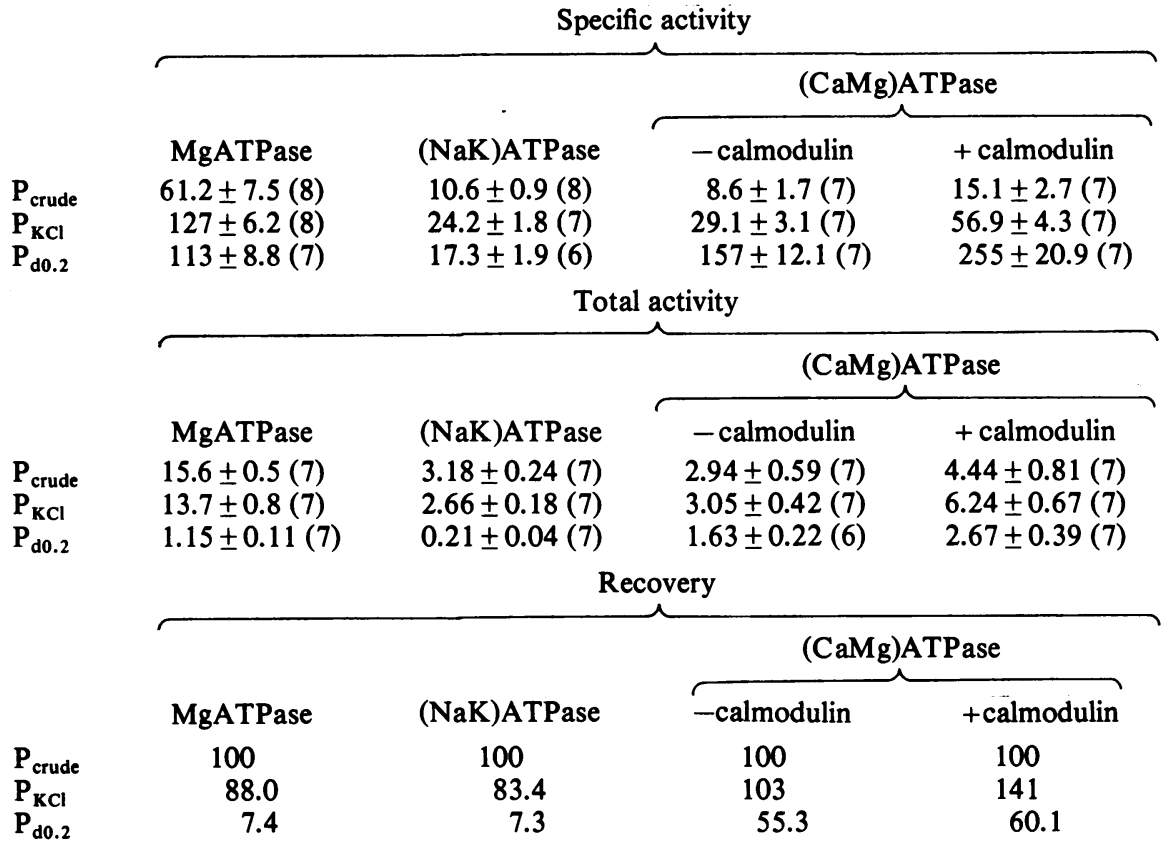

the $(\mathrm{CaMg}) \mathrm{ATPase}$ activity measured in the presence of calmodulin probably because calmodulin has been removed during the $\mathrm{KCl}$-wash procedure. This also explains a recovery of $140 \%$ in the $P_{\mathrm{KCl}}$ fraction compared with the $\mathbf{P}_{\text {crude }}$ (Table 2).

This partial purification of the $(\mathrm{CaMg}) \mathrm{ATPase}$ has resulted in an approx. 18-fold increase in the specific activity of the enzyme as compared with that in the crude microsomes. By contrast, the specific activities of the MgATPase and ( $\mathrm{NaK})$ ATPase were increased by a factor of less than 2 .

\section{Membrane reconstitution}

Removal of the detergent by dialysis at $22^{\circ} \mathrm{C}$ resulted in a reconstitution of membranes. This is indicated by the increased turbidity during the dialysis and by the fact that after dialysis a fraction could be sedimented by centrifugation at $223800 \mathrm{~g}$ for $30 \mathrm{~min}$. An electron-microscopic analysis of this fraction shows monolamellar vesicles. These vesicles are capable of an ATP-dependent $\mathrm{Ca}^{2+}$ uptake, which is further stimulated by oxalate (Fig. 1). $\mathrm{A} \mathrm{Ca}^{2+}$-transport system still functions after removal of the detergent.

Further purification of (CaMg)ATPase by density-gradient centrifugation

In some experiments we have attempted a further purification of the reconstituted vesicles by density-gradient centrifugation. The $\mathbf{P}_{\mathrm{d} 0.2}$ fraction $(0.5 \mathrm{ml})$ was therefore put on a $5.2 \mathrm{ml}$ linear sucrose density gradient prepared from solutions of $15 \%$ and $50 \%(\mathrm{w} / \mathrm{w})$ sucrose in water, in Beckman SW 50.1 tubes. The tubes were centrifuged for $16 \mathrm{~h}$ at $37000 \mathrm{rev} . / \mathrm{min}\left(160000 \mathrm{~g}_{\max }\right)$. At the end of the run two bands were visible, a large band at a concentration of $20 \%(w / w)$ sucrose, which contained the $(\mathrm{CaMg}) \mathrm{ATPase}$, and a sharp band at $40 \%$ sucrose.

This procedure results in a further purification of the $(\mathrm{CaMg})$ ATPase. Mean values for $(\mathrm{CaMg})$ ATPase activity of 216 and $314 \mathrm{nmol} \cdot \mathrm{mg}^{-1} \cdot \mathrm{min}^{-1}$ were obtained respectively in the absence and presence of calmodulin. Most important, however, is the observation that microsomes equilibrating at a density of $20 \%$ sucrose were devoid of a polypeptide band of 220000 daltons, which probably corresponds to contaminating myosin heavy chains. In the fraction equilibrating at $40 \%$ sucrose this 220000-dalton band is clearly visible on the dodecyl sulphate/polyacrylamide gel.

\section{Discussion}

After demonstrating the presence of a $(\mathrm{CaMg})$ ATPase in smooth-muscle microsomal fractions,

Vol. 198 
which is probably related to the ATP-dependent $\mathrm{Ca}^{2+}$-transport system (Wuytack \& Casteels, 1980; Wuytack et al., 1980), we decided to purify this enzyme further. The partial purification of the (CaMg)ATPase of the microsomal fraction of smooth muscle is described in the present paper.

Because the $\mathrm{Ca}^{2+}$-transport ATPase is a membrane enzyme, detergents were used for its purification. The deoxycholate procedure described by Meissner \& Fleischer (1974) was selected, because this detergent can be removed more easily than most other detergents. In view of the relatively low activity of the $(\mathrm{CaMg})$ ATPase in smooth-muscle microsomes, a large amount of smooth muscle was required to start the isolation procedure, and therefore the antrum of the pig stomach was chosen. Several inhibitors of proteolysis were included in the homogenization system, because during homogenization and detergent treatment proteinases may be activated. The ensuing proteolysis could not only damage the $\mathrm{Ca}^{2+}$-transport system, but could also interfere with the stimulation of the $\mathrm{Ca}^{2+}$-transport ATPase by calmodulin. It has been reported that mild proteolysis activates calmodulin-dependent phosphodiesterase (Cheung, 1971) and $\mathrm{Ca}^{2+}$ transport in erythrocytes (Sarkadi, 1980), making those activities thereby less sensitive to calmodulin.

The first purification step consists of a $\mathrm{KCl}$ wash. The data in Table 1 indicate that such a wash decreases the protein content of the microsomal fraction and that it increases the specific activities of the ATPases. The mean increase in the ( $\mathrm{CaMg})$ ATPase activity is slightly larger than that of the other ATPase activities. We find after a $\mathrm{KCl}$ wash of the microsomal fraction an increase in plateau value of $\mathrm{Ca}^{2+}$ accumulated in the absence of oxalate as well as an increased rate of $\mathrm{Ca}^{2+}$ transport in the presence of oxalate. These changes in transport characteristics appear smaller than one would expect from the diminution in protein content. Washing the microsomes with $\mathrm{KCl}$ might increase the $\mathrm{Ca}^{2+}$. permeability of some vesicles, resulting in an increase of the $\mathrm{Ca}^{2+}$-transport activity which is relatively smaller than the concomitant increase in ATPase activity.

The deoxycholate/protein ratio was chosen in such a way as to increase selectively the $(\mathrm{CaMg})$ ATPase activity. Whereas in the control preparation the $(\mathrm{CaMg}) \mathrm{ATPase}$ activity (measured in the presence of calmodulin) is only one-quarter of the MgATPase activity, in the final preparation it is about twice the corresponding value for the MgATPase (Table 2). The origin of this MgATPase in our microsomes is unclear. It is unlikely that mitochondrial fragments contribute considerably to this activity, because we measure the ATPase activity in the presence of azide. Even at a detergent/protein ratio of 2 , only $30 \%$ of the protein is solubilized. We have not used higher detergent/protein ratios because of its inactivating action on the $(\mathrm{CaMg}) \mathrm{ATPase}$ activity. The nature of the unsolubilized protein material has not been investigated, but one could assume that a considerable part of this protein fraction may consist of the cytoskeletal matrix and of membrane-associated matrix (Mescher et al., 1981).

Dodecyl sulphate/polyacrylamide-gel electrophoresis of the smooth-muscle microsomes shows peptide bands of 220000 and 45000 daltons, which probably indicate the presence of myosin heavy chains and of actin respectively. $\mathrm{KCl}$ extraction does not completely remove these bands. Even in our final $\mathbf{P}_{\mathrm{d} 0.2}$ fraction corresponding bands can still be observed. The question therefore arises whether a $\mathrm{Ca}^{2+}$-regulated actin-stimulated myosin ATPase could be responsible for the observed $(\mathrm{CaMg})$ ATPase activity. In a previous paper (Wuytack \& Casteels, 1980) we concluded that this is not the case in coronary-artery smooth muscle and that most of the $(\mathrm{CaMg}) \mathrm{ATPase}$ activity is probably related to the $\mathrm{Ca}^{2+}$-transport system. We have now more arguments in favour of this hypothesis. Under two experimental conditions we obtained $(\mathrm{CaMg})$ ATPase preparations that on dodecyl sulphate/polyacrylamide-gel electrophoresis no longer showed the 220000-dalton myosin bands, but nevertheless still had a high (CaMg)ATPase activity which could be stimulated by calmodulin. (1) The first preparation is obtained by isopycnic equilibration of $P_{d 0.2}$ fractions on sucrose gradients. The (CaMg)ATPase activity equilibrating at $20 \%$ sucrose has a higher specific activity of $(\mathrm{CaMg})$ ATPase than does the fraction before isopycnic equilibration, but it does not contain the 220000dalton band. (2) When microsomes (fraction $\mathbf{P}_{\mathbf{x C l}}$ ) are extracted with Triton X-100 the 220000 -dalton myosin band is not solubilized. The solubilized protein does, however, show (CaMg)ATPase activity, which can be activated by calmodulin (results not shown).

The presence of an ATP-dependent $\mathrm{Ca}^{2+}$-transport activity in the $P_{d 0.2}$ fraction further indicates that the $(\mathrm{CaMg}) \mathrm{ATPase}$ activity in this fraction may be due to a $\mathrm{Ca}^{2+}$-transport ATPase. That the specific activity of the $\mathrm{Ca}^{2+}$ transport in this fraction is not increased to the same extent as the $(\mathrm{CaMg}) \mathrm{ATPase}$ activity could be due to the presence in the detergent-treated fractions of a larger proportion of vesicles permeable to $\mathrm{Ca}^{2+}$.

The present preparation contains MgATPase and (NaK)ATPase activities, but the (CaMg)ATPase activity has been selectively enriched over the other two ATPases. If the pure $(\mathrm{CaMg}) \mathrm{ATPase}$ from smooth muscle has a specific activity comparable with that of skeletal-muscle or erythrocyte (CaMg)ATPase (Sarkadi, 1980), it would require another 
10-fold purification step in order to approach $100 \%$ purity.

This work was supported by grant no. 3.0087 .74 of the Fonds voor Wetenschappelijk Geneeskundig Onderzoek, Belgium.

\section{References}

Cheung, W. Y. (1971) J. Biol. Chem. 246, 2859-2869

Gietzen, K., Seiler, S., Fleischer, S. \& Wolf, H. U. (1980) Biochem. J. 188, 47-54

Laemmli, U. K. (1970) Nature (London) 227, 680-685

Lowry, O. H., Rosebrough, N. J., Farr, A. L. \& Randall, R. J. (1951) J. Biol. Chem. 193, 265-275
Meissner, G. \& Fleischer, S. (1974) J. Biol. Chem. 249, 302-309

Mescher, M. F., Jose, M. J. L. \& Balk, S. P. (1981) Nature (London) 289, 139-144

Nonomura, Y. \& Ebashi, S. (1980) Biomed. Res. 1, 1-14

Raeymaekers, L., Wuytack, F., Batra, S. \& Casteels, R. (1977) Pflugers Arch. 368, 217-223

Sarkadi, B. (1980) Biochim. Biophys. Acta 604, 159-190

Sharma, R. K. \& Wang, J. H. (1979) Adv. Cyclic Nucleotide Res. 10, 187-198

van Breemen, C. (1977) J. Physiol. (London) 272, 317-329

Wuytack, F. \& Casteels, R. (1980) Biochim. Biophys. Acta 595, 257-263

Wuytack, F., Landon, E., Fleischer, S. \& Hardman, J. G. (1978) Biochim. Biophys. Acta 540, 253-269

Wuytack, F., De Schutter, G. \& Casteels, R. (1980) Biochem. J. 190, 827-831 